\title{
Participants' Opinions on Andragogical Applications Based on the Communicative Teaching Method
}

\author{
Tanju DEVECI $\dot{I}^{*}$
}

\author{
Meral UYSAL ${ }^{* *}$
}

\begin{abstract}
This study investigated demographic characteristics of adults learning English, their reasons for participation and opinions about the andragogical applications based on the Communicative Teaching Method (CTM). Participants included 321 learners. The data were analyzed using descriptive statistics. Pearson's chi-square test was used to compare the data. The findings indicated that the majority of the participants were female, they held a university degree, and were in the early adulthood periods. The two main reasons for participation were developing practical skills and improving intellectual knowledge. The data analysis revealed their lessons were not totally based on andragogical applications based on CTM. There were differences in participants' opinions according to their education levels, suggesting less positive thinking as the education level increased. While there were no significant differences in terms of gender, those in the higher age group had a more positive attitude regarding the use of the andragogical application based on CTM.
\end{abstract}

Keywords: The Communicative Teaching Method, andragogy, participation, adult education

\footnotetext{
Assist. Prof., Petroleum Institute, Arts and Sciences Program, Abu Dhabi, the UAE E-mail: tanjudeveci@yahoo.com

** Prof. Dr., Ankara University Faculty of Educational Sciences, Ankara, Turkey.

E-mail: muysal@education.ankara.edu.tr
} 


\section{SUMMARY}

Purpose and Significance: Adults' needs for participation can be addressed best by adopting the andragogical approach. This study offers a set of principles for teaching foreign languages to adults with a focus on andragogy and the Communicative Teaching Method (CTM). It focuses on reasons for participation, and the andragogical orientations based on the CTM. An identification of the shared principles of both approaches can contribute to language teaching. It can help avoid strict pedagogical orientations in teaching adults, as found in earlier research (Cox, 2013; Kovacevic, 2011). This study also emphasizes that andragogical orientation can increase academic achievement, as suggested by empirical research (Bishop, 2006; Akin, 2011).

Method: The survey method, which included a two-part data gathering instrument, was used. The first part asked demographic information. The second part aimed at determining the participants' feelings about the principles of the andragogical applications based on CTM as reflected in their classes. 321 learners participated in the study. The data were analyzed using descriptive statistics. Comparison of the data sets according to different variables was conducted using Pearson's chi-square test.

Results: The results showed that the majority of the participants (\%69.5) were female. More of the participants (\%71.3) was in the early adulthood age period. The most frequent reason for participation was developing practical skills (\%53.3). Other work related reasons were also present. It was found that the applications were not generally based on the andragogical applications based on CTM. The learners at Kadikoy Adult Education Center gave more negative responses to the items regarding using the target language and pair/group work. The data analysis according to gender showed no statistically significant difference. However, those in the lower age group thought that they did not use the target language as the main communication tool, their life experiences were not much exploited, but they did contribute to formulating lesson aims. It was found that the learners with higher education levels thought less positively about the use of these principles in their classes.

Discussion and Conclusion: Overall, the participants did not feel their needs as adult learners were addressed. Kadikoy Adult Education Center in particular was less likely to consider the expectations of an andragogical 
approach based on CTM. Learners' ages and educational levels made a difference in their evaluations of the effectiveness of the programs. This can reduce satisfaction levels. To reduce attrition rates in adult education, adult learners' demographic characteristics and their reasons for participation should be considered. Learners should raise their awareness of own characteristics and be active in their learning process. Planners and practitioners of adult education activities should be offered both pre-service and in-service training about the andragogical applications based on CTM. 



\title{
İletişimsel Öğretim Yöntemi’ ne Dayalı Andragojik Uygulamalara İlişkin Katılımcı Görüşleri
}

\author{
Tanju DEVECI * \\ Meral UYSAL
}

ÖZ. Bu araștırmada İngilizce öğrenen yetişkinlerin demografik özelliklerinin, katılım nedenlerinin ve öğrenim gördükleri kurumlardaki uygulamalara ilişkin görüşlerinin belirlenmesi amaçlanmaktadır. Çalışma grubunu Kadıköy Halk Eğitim Merkezi, Sabancı Üniversitesi Diller Okulu ve Özel Özkent Lisan Kursu'nda İngilizce öğrenen 321 yetişkin oluşturmuştur. Veriler, araştırmacılar tarafindan geliştirilen bir veri toplama aracı ile toplanmıştır. Verilerin analizinde tanımlayıcı istatistikler kullanılmıştır. Kurumlar ve yaş gibi farklı türden değişkenlerin kıyaslanmasında Ki-kare testi kullanılmıştır. Sonuçlar, katılımcıların çoğunluğunun kadınlardan oluştuğunu, ilk yetişkinliğe geçiş ve ilk yetişkinlik döneminde bulunduklarını, yükseköğretim diplomasına sahip olduklarını göstermektedir. Katılım nedenleri arasında en yaygın olarak pratik beceriler geliştirme ve gelir düzeyini artıracak nedenler olduğu belirlenmiş̧ir. Eğitim programlarının İletişimsel Öğretim Yöntemi'ne dayalı andragojik uygulama ilkelerine tamamen uymadığı görülmüştür. Eğitim seviyesi ile katılımcı görüşleri arısında ters orantılı bir ilişki bulunmuştur. Ayrıca daha ileri yaş grubundaki öğrenenlerin daha olumlu hisler beslemekle birlikte andragojik temelli uygulamaların tamamen gerçekleşmediğini düşündükleri belirlenmiştir. Cinsiyete göre ise katılımcı görüşleri arasında fark olmadığı ortaya çıkmıştır.

Anahtar Sözcükler: İletişimsel Öğretim, andragoji, katılım, yetişkin eğitimi.

\footnotetext{
Yar. Doç. Dr., The Petroleum Institute, Arts and Sciences Program, Abu Dhabi, the UAE E-mail: tanjudeveci@yahoo.com

Prof. Dr., Ankara Üniversitesi Eğitim Bilimleri Fakültesi, Ankara, Türkiye.

E-mail: muysal@education.ankara.edu.tr
} 


\section{GİRIŞ}

Bilgi teknolojilerindeki gelişmeler ve bu teknolojilere ulaşılabilirlik derecesindeki artışla birlikte bilgi çağına girmiş durumdayız. Sürekli olarak geliştirilen bilgilere ulaşılabilirlik derecesinin belirleyicilerinden biri yabancı bir dil bilmektir. Uluslararası bir dil olarak İngilizceye yönelik farklı bir ilgi söz konusudur ve gerek örgün gerekse yaygın eğitim kurumlarında yabancı dil öğretimine yönelik çabalar yoğunlaşmıştır.

Yeni teknolojilerin uluslararası pazarda tanitılmasinda İngilizcenin kullanılmakta olması, bu dile hakim olmayan yetişkinlerin kendilerini dezavantajlı hissetmelerine sebep olmaktadır. Örgün eğitimden ayrılmış veya yeterince faydalanamamış yetişkinler, iş yaşamlarının bir gerekliliğgi olarak yetişkin eğitimi faaliyetlerine katılarak İngilizce öğrenmek istemektedirler. Ülkemizde bu yetişkinlere hizmet veren kurumlar arasında Halk Eğitim Merkezleri, sivil toplum kuruluşları, üniversitelere bağlı dil okulları ve özel eğitim kurumları bulunmaktadır.

Dil öğretimine yönelik olarak geliştirilen yeni öğretim yaklaşımlarının ne derece takip ediliği konusunda çekinceler vardır. İngilizce öğretiminin etkili şekilde nasıl gerçekleşebileceği üzerine yapılan tartışmalar ve araştırmalara bağlı olarak iletişimsel beceriden (communicative competence) bahsedilmeye başlanmıştır. Bununla kastedilen, istenenin ifade edilmesi, yorumlanması ve uzlaşmaya varılabilmesidir (Savignon, 2002). Bu iletişimsel ihtiyaçların göz önünde bulundurulmasını gerekli kılmıştır. Bu konudaki çalışmalar "İletişimsel Öğretim Yöntemi" (İ. Ö. Y.) (Communicative Teaching Method) kavramının gelişmesine neden olmuştur. $\mathrm{Bu}$ yöntem, etkileşimi hem araç hem amaç olarak ele alır. Dilbilim, felsefe, sosyoloji ve eğitim gibi bilim dallarının söylemlerinden içeriklere sahiptir (Savignon, 2002). Hedef dilin fonksiyonel amaçla öğrenilmesi gerektiğini vurgular. Hedef, öğrenenlere anlam oluşturmaları için yardımcı olmaktır (Segalowitz ve Lightbown, 1999). Dilin ne kadar başarılı öğrenildiği, öğrenenlerin iletişimsel yeterliliklerini ne derece geliştirmiş oldukları ile ölçülür. Okuma, dinleme, yazma ve konuşma olarak dört temel becerinin geliştirilmesi hedeflenir. Bu becerilerin birbirleri ile etkileşim halinde olduğu ve dilbilgisi ile kelime öğretiminin bu becerilerden soyutlanmadan, iletişime dayalı olarak öğretilmesi hedeflenir.

İ. Ö. Y. farklı öğrenenlerin farklı iletişimsel ihtiyaçları olacağını kabul eder ve bunların öğrenme süreçlerinde dikkate alınması gerektiğini vurgular. Öğrenenlere neyi nasıl öğrenmek istedikleri konusunda karar vermelerine yardımcı olunur. Öğretmen gücü, sorumluluğu ve kontrolü birinci günden öğrenenlere devretmez. Ancak öğrenenlerden nihai olarak kendi öğrenmelerine dair sorumluluk üstlenmeleri beklenir. Öğrenen merkezli bir 
ortamda, dil edinimin en üst düzeye çıkarılabilmesi için öğrenenler arası etkileşime izin verecek faaliyetlerden faydalanılır (Nunan, 1999: 10 -12).

İ. Ö. Y.'nde öğretmenlerin rolü farklılaşır. Richards ve Rogers (1986: 78) öğretmenlerin iki temel rolü olduğunu belirtmektedir. İlki, katılımcılar arasındaki iletişimi kolaylaştırmaktır. İkincisi, bağımsız bir katılımcı olmaktır. Öğretmen kaynakları organize eder, ama kendisi de bir kaynak, araştırmacı ve öğrenendir. Ayrıca, sürecin isleyişini gözlemler. Öğrenenleri ders hedeflerini ve öğrenme yaşantılarını belirlenme sürecine katar (Mangubhai, Marland, Dashwood ve Son, 2004). Öğrenenlerin müzakerelerde bulunduğu, iş birliği içerisinde çalıştıkları türden grup faaliyetleri kullanır. Dersler öğretmen değil, öğrenen merkezlidir.

Finnochiaro ve Brumfit (1983: 91-93) dil öğrenmenin, bireyin kişiliğini oluşturan kimliğinden ve sosyal davranışlarından ayrıştırılamayacağını söyler. Buna ilişkin özellikler arısında şunlar vardır:

- Önemli olan anlam ve iletişimsel yetidir.

- Konuşmalar iletişimsel işlevlere göre düzenlenmelidir.

- Dil öğrenimi, iletişim kurmayı öğrenmekle eşit tutulabilir.

- Telaffuzun anlaşılır olması yeterlidir.

- Dilbilgisi, öğrenenler iletişim kurmak üzere çabalarken daha iyi öğrenilir.

- Öğretmenin görevlerinden biri öğrenenleri motive etmektir.

- Deneme yanılma yoluyla öğrenme esastır.

- Sınıf faaliyetler arasında grup ve ikili çalışmalar yoğunluktadır.

Yetişkinlerde öğrenmenin sosyal dinamikleri göz önüne alındığında, İ. Ö. Y.'nin uygulandığı dil öğretim programlarında, yetişkinlerde öğrenme ilkelerini belirleyen andragojik yaklaşımın etkileri görülebilir. Andragoji terimi ilk olarak 1833'te Plato'nun eğitim teorisini tanımlamak üzere Alman bir öğretmen olan Alexandar Kapp tarafından kullanılmış, Malcolm Knowles tarafindan yetişkinlerde öğrenmeye ilişkin olarak kullanılmaya başlanmasıyla birlikte popülerlik kazanmıştır (Davenport \& Davenport, 1985: 4). Terim, Yunanca andr kökünden gelen ve 'adam' anlamını taşıyan kelimeden türemiştir (Knowles, 1980: 37-38).

Malcolm Knowles (1980: 39) yetişkinlerde öğrenmenin altında yatan varsayımları şöyle sıralar:

... kişi olgunlaşırken, (1) benlik kavramı bağımlı kişiden kendini yöneten kişiye doğru gider; (2) öğrenme için kaynak oluşturacak deneyimler depolar; (3) öğrenmeye hazır oluşu sosyal rollerine ait gelişimsel görevlere uygunluk düzeyinde gerçekleşir; (4) bilginin ileri bir zamanda kullanılmasından çok hemen kullanılmasını ister ve dolayısıyla öğrenmede konu merkezli olmaktan çok sorun merkezlidir. 
Andragojik modelde öğrenenlerin rolleri geleneksel öğrenci rollerinden farklılaşmaktadır. Yetişkinlerden öz yönetimli olmaları beklenir. Öğrenme hedefleri, süreçleri ve içerikleri konularında seçeneğe sahip olan yetişkinlerin seçimlerine ilişkin karar verme durumunda oldukları için sorumluluk duyguları gelişmiş olacaktır. Eğitimciden öğrenmeyi zenginleştirici bir ortam sağlaması ve öğrenme süreci üzerinde kontrolü öğrenenlere bırakması beklenir (Davenport ve Davenport, 1986). Dolayısılya andragojik yaklaşımda öğretmen kolaylaştırıcı rolü üstlenir. Knowles (1996: 118 -117) kolaylaştırıcının rolleri arasında şunları saymaktadır: a. Öğrenenlerin fiziksel ve psikolojik olarak rahat hissedebilecekleri bir ortam oluşturma, b. Öğrenenlerle birlikte planlama mekanizması oluşturma, c. Öğrenenlerin, eğitim öncesi nerede oldukları ve eğitim sonrasında nerede olmayı istedikleri arasındaki farka dair öğrenenlerle birlikte hedef belirleme, d. Yetişkin öğrenenlerin öz-yönetimli araştırma becerileri geliştirmelerini destekleyip öğrenme amaçları belirlemelerine yardımcı olma. e. Öz-tanılama işlemleri aracılığıyla öğrenenler tarafından tanımlanmış olan sorun alanlarını seçme, öğrenme için uygun biçimleri belirleme, yaşantısal öğrenme birimlerini tasarlama, belirlenen yöntem ve materyalleri uygun sirayla kullanma, f. Öğrenme etkinliklerinin andragojik modele uygun olarak yürütülmesi için personeli hizmet öncesi ve hizmet içi eğitim programlarıla yetiştirme, g. Öğrenenlerin programı değerlendirmelerine katılmasını sağlama. Davenport ve Davenport (1985) bu rolleri üstlenen öğretmenin faydalanabileceği öğrenme teknikleri arasında grup tartışmaları, rol oynama ve örnek olay incelemeleri bulunduğunu belirtmektedir.

Yukarıdaki açıklamalar, İ. Ö. Y. ilkelerinin yetişkin öğrenenlerin özellikleri ile örtüştüğünü göstermektedir. Öğrenen merkezli yapı her iki yaklaşımda da dikkati çekmektedir. Bu, her iki yaklaşımda da öğrenenlerin, kendi öğrenmeleri ile ilgili olarak sorumluluk üstlenmeleri vurgusundan anlaşılmaktadır. Ayrıca, her iki yaklaşımda da öğrenenlerin bilgi ve yaşam tecrübeleri kaynak olarak görülerek, öğrenenlerin gerek kendi öğrenmeleri gerekse diğer katılımcıların öğrenmesine katkıda bulunması hedeflenir. Bir takım farklılıklar da bulunmaktadır. Örneğin andragojik yaklaşımda öğrenenlerin en baştan itibaren, neyi, nasıl öğrenmek istedikleri ve nasıl değerlendirilmek istedikleri konularında karar alma ve planlama süreçlerine dahil edilmesi hedeflenirken, öğrenen merkezli yaklaşımda bunun başarılması ilk aşamalarda mümkün olmayabilir. Her iki yaklaşımın da kontrolü yetişkin öğrenenlere bırakmayı hedeflemeleri ortak bir unsur olarak değerlendirilebilir.

Eğitimcinin kolaylaştırıcı rolü her iki yaklaşımda da vurgulanmaktadır. Kolaylaştırıcı öğrenenlerle eşit durumdadır. Onlarla birlikte ve hatta onlardan öğrenebilir. 
Dil öğretiminde, işbirliğine dayalı bir öğrenme süreci olan İ. Ö. Y.’nin en etkili sonuçları vereceği düşünülebilir. Andragojik modelin de gerek öğrenenlerle diğer öğrenenler, gerekse öğrenenler ile kolaylaştırıcı arasındaki işbirlikçi ruhu göz önünde bulundurulursa, yetişkinlere yönelik İ. Ö. Y.'nin benimsendiği dil eğitimi programlarında andragojik modelin varsayımlarının dikkate alınması gerekliliği görülebilir.

Bir dersin iletişimsel öğrenme deneyimi üzerine inşa edilip edilmediğini belirlemek üzere şunlara bakılması gerekir (Nunan, 1991):

- Sınıf içi etkileşimde hedef dil kullanılmalıdır.

- Gerçek yaşamdan alınan materyaller kullanılmalıdır.

- Öğrenenler hem dil hem öğrenme yönetim süreçlerine odaklan malıdır.

- Öğrenenlerin yaşam deneyimlerinden faydalanılmalıdır.

- Sınıf içerisinde yapılan faaliyetlerle sınıf dışında gerçekleşen faaliyetler arasında bağ kurulmalıdır.

- Öğrenenlere, öğrenme süreci üzerinde kontrol sahibi oldukları hissettirilmelidir.

- Ders hedeflerinin belirlenmesinde öğrenenlerin katkısı olmalıdır.

- Ders içi ne tür faaliyetlerin yapılabileceği konusunda öğrenenler fikirlerini verebilmelidir.

- Öğrenenlerin ikili ve gruplar halinde çalışmalarına izin verilmelidir.

Görüleceği üzere bu maddeler andragojik modelle ortak söylemlere sahiptir. Dolayısıyla yetişkinlere yönelik olarak düzenlenen yabancı dil eğitimi programlarında İ. Ö. Y.'ne dayalı andragojik varsayımların dikkate alınması gereklidir. Yabancı dil öğrenen yetişkinlerin eğilimleri üzerine yapılan araştırmalar, yetişkinlerin andragojik eğilimler taşıdığını göstermiştir. Örneğin, Deveci (2007: 22), yetişkin öğrenenlerin tutumlarında katı olmamakla birlikte andragojik yaklaşıma eğilimli olduğunu belirlemiştir. Deveci (2007: 22-23), yetişkin öğrenenlerin dili hangi amaçla öğrenmek istediklerinin yetişkinlerle birlikte hedeflenmesi gerektiğini ve özellikle sosyal iletişimlerini geliştirmek ve güçlendirmek ve temel ihtiyaçlarını karşılamak gibi nedenlerle dil öğrenmek isteyen yetişkinler için İ. Ö. Y.'nin benimsenmesi gerektiğini belirtmektedir. Ayrıca, bu yöntemin öğrenen merkezli öğrenme ilkelerinin de vurguladığı gibi, henüz andragojik eğilim taşımayan öğrenenlerin göz ardı edilmemesi gerektiği, pedagojik temelli eğitim prensiplerinden de faydalanarak adım adım andragojik temelli faaliyetlerle tanışmalarına izin vermek koşuluyla yetişkinlerin kendileri için en iyi neyin olduğuna yine kendilerinin karar vermesine yardımcı olunması gerektiğinin belirtmektedir. Yabancı bir dil öğrenen yetişkin sosyalleşme süreci içerisinde pasif kalmayı öğrenmiş ise, öğrenme sürecine katabilecek bir şeyi olmadığına ve yeterli olgunluğa ulaşmadığına inanarak kendine bu 
şekilde davranılacağı korkusuyla, öğrenme ortamına girdiğinde pasif kalabilir (Bangura, 1996).

Andragojik ilkelere göre geliştirilmiş problem temelli İngilizce eğitiminin etkinliğini incelediği araştırmasında Akın (2010), katılımcıların dil öğrenimine ilişkin ihtiyaçlarını belirlemiş ve ihtiyaç analizi doğrultusunda andragojik ilkelere göre problem temelli ve özel amaçlı bir mesleki İngilizce eğitim programı hazırlayıp uygulamıştır. Bu program, öğrencilerin hissettikleri ihtiyaçlara dayandığ 1 ve İ. Ö. Y.'nin de vurguladığg 1 dört temel beceri (okuma, dinleme, yazma ve konuşma) dikkate alınarak yürütüldüğü için öğrencilerin güdülenmesini olumlu etkileyerek başarı düzeylerinde artış olduğu belirlenmiştir.

Andragojik modeli, İngilizce öğrenen Japon öğrenenler üzerinde denediği çalışmaları sonucunda Brown (2002) da, öğrenenlerin başarı düzeylerinin arttığını belirlemiştir. Bunun temel nedeninin eğitmenin, öğrenenlerin ihtiyaçları ve hedeflerini dikkate alması, gerçek hayatta kullanabilecekleri faaliyetlerinin ders ortamına getirmesi, yabanc1 dil öğrenirken edindikleri "ikinci" bir kimlikten kaynaklanan kırılgan, savunmacı ve ön yargılı tutumları dikkate alması gibi andragojik modelin önemli ilkelerine uyulması olduğunu belirtir.

McCombs (1991: 118) öğrenmenin, diğer insanlarla etkileşim ve iletişim içerisinde bulunulduğunda kolaylaşacağını söyler. $\mathrm{Bu}$, hem İ. Ö. Y.'nde hem andragojik modelde vurgulanmaktadır. Bireyler yaş, kültür, cinsiyet gibi farklı değişkenlerin söz konusu olduğu işbirlikçi ortamlarda etkileşim ve iletişimde bulunduklarında farklı görüş, düşünce ve öğrenme strateji ve stilleri ile tanışarak diğerlerini ve kendilerini daha iyi tanıyacaklar ve problem çözme becerileri ile sosyal yeterlilikleri gelişecektir.

Türkiye'de yetişkinlere yabancı bir dil olarak İngilizce eğitimi konusunda hizmet veren kurumlardaki yetişkin öğrenenlerin sayıları göz önünde bulundurulduğunda, dil eğitiminin andragojik ilkelere uygun şekilde verilmesi gerekliliği belirginleşir. Türkiye'deki Halk Eğitim merkezlerinden Ankara ilinde bulunan 3 tanesindeki İngilizce öğretiminde yöntemlerin, andragojik ilkelere uygunluğu Aşır (2009) tarafindan incelenmiş ve benlik ve ihtiyaca dayalılık ilkelerinin orta düzeyde, deneyim ve sorun temelli eğitim ilkesinin yüksek düzeyde dikkate alındığı belirlenmiştir.

Yukarıdaki tartışmaların ışığında, yabancı dil öğreten kurumlardaki eğitimlerin, İ. Ö. Y. ile andragojinin örtüşen ilkeleri dikkate alınarak yürütülmesi halinde başarı düzeyinin arttırılacağı savunulabilir. Ancak genel olarak ülkemizde yetişkinlere yönelik olarak düzenlenen yabancı dil programlarında, yetişkinlerin özelliklerini dikkate alan andragojik temelli İ. Ö. Y.'nin dikkate alınmadığ 1 görülmektedir. Ayrıca yabancı dil öğrenmek isteyen yetişkinlerin katılım nedenleri ve demografik özelliklerine göre dahil 
oldukları eğitim süreçlerine ilişkin görüşlerinin belirlenmesi gereklidir. Bu problem durumundan yola çıkan bu araştırmanın, katılımcıların yabancı dil öğrenme nedenlerini belirlemesi, yetişkin eğitimi ilkelerinin temelini oluşturan andragojik yaklaşımın yabancı dil öğretimine uyarlanması konusunda alana katkıda bulunacağı umulmaktadır. Ayrıca, farklı eğitim kurumlarında yabancı bir dil (İngilizce) öğrenmekte olan yetişkinlerin demografik özelliklerinin belirlenmesi ve bu özelliklere göre yetişkinlerin katıldıkları programları İ. Ö. Y. temelli andragojik ilkelere göre değerlendirmesi, ülkemizde yetişkinlere yabanc1 dil öğretiminin yeterliliğinin değerlendirilmesine katkıda bulunacaktır. $\mathrm{Bu}$ amaçla araştırmada şu sorulara yanıt aranmıştır:

Milli Eğitim Bakanlığı, Çıraklık ve Yaygın Eğitim Genel Müdürlügü’ne bağlı Kadıköy Halk Eğitim Merkezi, Sabancı Üniversitesi’ne bağlı Diller Okulu ve Milli Eğitim Bakanlığı, Özel Eğitim Kurumları Genel Müdürlüğü'ne bağlı İstanbul Özel Özkent Lisan Kursu isimli eğitim kurumlarında İngilizceyi yabancı bir dil olarak öğrenmekte olan;

- Yetişkinlerin demografik özellikleri (cinsiyet, yaş, eğitim durumu) nelerdir?

- Yetişkinlerin katılım nedenleri nelerdir?

- Yetişkinlerin, İletişimsel Öğretim Yöntemi’ne dayalı andragojik uygulamalara yönelik görüşleri nelerdir?

\section{YÖNTEM}

\section{Araştırmanın Modeli}

$\mathrm{Bu}$ araştırma tarama modeli esas alınarak yürütülmüştür. Tarama modelleri, geçmişte ya da halen var olan bir durumu var olduğu şekilde betimlemeyi amaçlayan araştırma yaklaşımıdır (Karasar,1994, 77). Araştırma, İngilizceyi yabancı bir dil olarak öğrenen yetişkinlerin katılım nedenleri ve öğretim süreçlerine ilişkin görüşleri doğrultusunda yapılmıştır ve öğretim sürecine müdahalede bulunulmamıştır.

\section{Çalıșma Grubu}

Araştırmanın çalışma grubunu Kadıköy Halk Eğitim Merkezi, Sabancı Üniversitesi'ne bağlı Diller Okulu ve İstanbul Özel Özkent Lisan Kursu isimli eğitim kurumlarında 2009-2010 akademik takvimde İngilizceyi yabancı bir dil olarak öğrenmekte olan 455 yetişkin oluşturmuştur. Çalışma gurubu içerisinde, 22 Kasım 2009 ve 30 Ocak 2010 tarihleri arasında 
Kadıköy Halk Eğitim Merkezi’nden 199, Sabancı Üniversitesi Diller Okulu'ndan 68 ve Özel Özkent Lisan Kursu'ndan 54 olmak üzere toplam 321 yetişkine ulaşılabilmiştir. Araştırmaya katılan yetişkinlerin 223'ünü kadın ve 98'ini erkek yetişkin öğrenen oluşturmuştur.

\section{Veri Toplama Aracı}

Araştırmada, iki bölümden oluşan bir veri toplama aracı kullanılmıştır. Aracın birinci bölümünde katılımcılara ait demografik bilgileri (yaş, cinsiyet, eğitim düzeyi) ve katılım nedenlerini belirlemek üzere sorular sorulmuştur. Veri toplama aracının ikinci bölümünde ise katılımcılara, çalışmanın yürütüldüğü kurumlardaki yabancı dil öğretiminde İ. Ö. Y.'ne dayalı andragojik uygulamalara yönelik görüşleri sorulmuştur. 9 sorudan oluşan bu bölümün geliştirilmesinde alanyazında yer alan kaynaklardan yararlanılmıştır ve İ. Ö. Y. ilkeleri ile andragojik modelin örtüşen özellikleri göz önünde bulundurularak hazırlanan taslak, uzman görüşüne sunulmuştur. Uzmanlardan alınan görüşler doğrultusunda ilgili bölüme son biçimi verilmiştir. Katılımcılardan, verilen 9 ifade ile hemfikir olup olmadıklarını belirtmeleri istenmiştir.

\section{Verilerin Analizi}

$\mathrm{Bu}$ çalışmada elde edilen veriler SPSS (version 18.0) (SPSS Inc., Chicago, USA) kullanılarak analiz edilmiştir. Çalışma grubunu tanımlamak için frekans dağılımı, ortalama, standart sapma gibi tanımlayıcı istatistikler kullanılmıştır. Katılımcıların uygulamalara yönelik görüşlerinin demografik özelliklere göre incelenmesinde Ki-kare testi kullanılmıştır. Analizlerde farkl11ıkların belirlenmesi için \% 95 anlamlılık düzeyi kullanılmıştır.

\section{Araştırmanın Sınırlılıkları}

$\mathrm{Bu}$ araştırmanın sınırlılıkları şunlardır:

- Araştırmaya katılanların ne kadar zamandır İngilizce öğrenmekte oldukları dikkate alınmamıştır.

- Araştırmaya katılan yetişkin öğrenenlerin uygulamalara ilişkin görüşlerinin belirlenmesinde, İ. Ö. Y.'nin yalnızca andragojik model ile örtüştüğü varsayılan ilkeleri ile sınırlı kalınmıştır.

- Araştırma için verilerin toplandığ 1 kurumlarda görev yapan eğitmenler ve yöneticilerin yöntem ve uygulamalara ilişkin görüşleri alınmamış, yalnızca öğrenenlerin görüşleri ile sınırlı kalınmıştır. 


\section{BULGULAR}

\section{Katılımcıların Demografik Özelliklerine İlişkin Bulgular}

Araştırmaya katılan yetişkin öğrenenlere ilişkin elde edilen demografik bilgiler Tablo 1'de verilmiştir.

Tablo 1. Katılımclların demografik özellikleri

\begin{tabular}{|c|c|c|c|c|c|c|c|c|c|c|}
\hline \multirow[b]{2}{*}{ Kurum } & \multicolumn{2}{|c|}{ Cinsiyet } & \multicolumn{4}{|c|}{ Yaş } & \multicolumn{4}{|c|}{ Eğitim Durumu } \\
\hline & $\begin{array}{c}\text { Kadın } \\
f ; \% \%\end{array}$ & $\begin{array}{c}\text { Erkek } \\
\text { f;\% }\end{array}$ & $\begin{array}{c}17-40 \\
\mathrm{f} ; \%\end{array}$ & $\begin{array}{c}41-60 \\
\mathrm{f} ; \%\end{array}$ & $\begin{array}{c}>61 \mathrm{f} ; \\
\%\end{array}$ & $\begin{array}{c}\text { En } \\
\text { düşük; } \\
\text { En } \\
\text { yüksek }\end{array}$ & $\bar{X}$ & İ. Ö. & L. & Y. Ö. \\
\hline Kadıköy & 159 & 40 & 122 & 71 & $6 ; 3$ & & & $6 ; 3$ & 58 & 135 \\
\hline H.E.M. & 79.9 & 20.1 & 61.1 & 35.9 & & & & & 29 & 68 \\
\hline Sabancı & 32 & 36 & 59 & 9 & $0 ; 0$ & & & $0 ; 0$ & 16 & 52 \\
\hline Üni. D.O & 47.1 & 52.9 & 86.8 & 13.2 & & 19; & 33.8 & & 23.2 & 76.5 \\
\hline Ö. & 32 & 22 & 48 & 6 & $0 ; 0$ & 82 & & $0 ; 0$ & 8 & 46 \\
\hline $\begin{array}{l}\text { Özkent } \\
\text { L. Kursu }\end{array}$ & 59.3 & 40.7 & 88.9 & 11.1 & & & & & 14.8 & 85.2 \\
\hline TOPLAM & $\begin{array}{l}223 \\
69.5\end{array}$ & $\begin{array}{l}98 ; \\
30.5\end{array}$ & $\begin{array}{l}229 \\
71.3\end{array}$ & $\begin{array}{c}86 \\
26.8\end{array}$ & $6 ; 1.9$ & & & $\begin{array}{l}6 ; \\
1.5\end{array}$ & $\begin{array}{c}82 ; \\
25.9\end{array}$ & $\begin{array}{l}233 ; \\
72.6\end{array}$ \\
\hline
\end{tabular}

Tablo 1'den anlaşılacağ1 üzere, üç ayrı kurumda yabanc1 dil eğitimi almakta olan yetişkinlerin çoğunluğunu 223 kişi ile (\%69.5) kadınlar oluşturmuştur. Erkek katılımcıların sayısının ise 98 (\%30.5) olduğu belirlenmiştir.

Katılımcıların yaşlarına ilişkin olarak elde edilen verilerin analizi ise, katılımcıların yaşlarının 19 ile 82 arasında değişiklik gösterdiğini ve yaş ortalamalarının 33.8 olduğunu göstermiştir. Katılımcıların çoğunluğu (\%71.3) ilk yetişkinliğe geçiş ve ilk yetişkinlik dönemini oluşturan 17-40 yaş arası bireylerden oluşmaktadır. Bunu, 86 kişi (\%26.8) ile 41-60 yaşlarını kapsayan orta yetişkinliğe geçiş ve orta yetişkinlik dönemi izlemiştir. İleri yetişkinliğe geçiş ve ileri yetişkinlik döneminden yalnızca $6(\% 1.9)$ yetişkin çalışmaya katılmıştır. Kadıköy Halk Eğitim Merkezi'nde dil eğitimi almakta olan yetişkinlerin, Sabancı Üniversitesi Diller Okulu ve Özel Özkent Lisan Kursu'ndan araştırmaya katılan öğrenenlere kıyasla daha ileri yaş grubunda oldukları belirlenmiştir. Bu kurumdan araştırmaya katılan yetişkinlerin orta yetişkinlik (\%35.9) ve ileri yetişkinlik dönemlerindeki oranın (\%3), diğer iki kurumdaki bu yaş gruplarının oranından daha yüksek olduğu görülmektedir.

Katılımcıların eğitim durumları dikkate alındığında, çoğunluğu (\%72.6) bir yükseköğretim kurumundan mezun bireylerin oluşturduğu görünmektedir. 
$\mathrm{Bu}$ grup katılımcıların her üç kurumda çoğunluğu oluşturduğu dikkati çekmektedir. En son bir ilköğretim düzeyinde okuldan mezun olan yetişkinlerin oranın ise $\% 1.5$ olduğu belirlenmiştir. Bu yetişkinlerin, yalnızca Kadıköy Halk Eğitim Merkezi’nde eğitim aldıkları dikkati çekmektedir.

\section{Katılım Nedenleri}

Araştırmanın ikinci amacı, araştırmaya katılan yetişkinlerin hangi nedenlerden dolayı İngilizce öğrenmek istediklerinin belirlenmesi idi. $\mathrm{Bu}$ amaca yönelik olarak elde edilen bulgular Tablo 2'de görülmektedir.

Tablo 2. Katılım nedenleri dă̆ılımı*

\begin{tabular}{|c|c|c|c|c|c|c|c|c|}
\hline \multirow{2}{*}{ Katılım Nedeni } & \multicolumn{2}{|c|}{ K. H.E.M. } & \multicolumn{2}{|c|}{ S.Ü. D.O. } & \multicolumn{2}{|c|}{ Ö.Ö.L.K. } & \multicolumn{2}{|c|}{ TOPLAM } \\
\hline & $\mathrm{f}$ & $\%$ & $\mathrm{f}$ & $\%$ & $f$ & $\%$ & $\mathrm{f}$ & $\%$ \\
\hline Bir iş bulabilmek & 36 & 18.1 & 0 & 0 & 8 & 14.8 & 44 & 13.8 \\
\hline Meslekte ilerlemek & 60 & 30.2 & 54 & 79.4 & 37 & 68.5 & 151 & 47 \\
\hline $\begin{array}{l}\text { Akademik kariyer } \\
\text { yapabilmek }\end{array}$ & 31 & 15.6 & 14 & 20.6 & 19 & 35.2 & 64 & 19.9 \\
\hline Pratik beceriler geliştirmek & 113 & 57 & 37 & 54.4 & 21 & 38.9 & 171 & 53.3 \\
\hline $\begin{array}{l}\text { Genel kültür düzeyini } \\
\text { artırmak }\end{array}$ & 99 & 49.8 & 37 & 54.4 & 27 & 50 & 163 & 50.8 \\
\hline $\begin{array}{l}\text { Sosyal bağları } \\
\text { artırmak/güçlendirmek }\end{array}$ & 74 & 37.2 & 33 & 16.6 & 20 & 37 & 127 & 39.6 \\
\hline Diğer & 12 & 6 & 5 & 7.4 & 2 & 3.7 & 19 & 5.9 \\
\hline
\end{tabular}

Tablo 2'de görüleceği gibi, çalışmaya katılan yetişkinler arasında en sık dile getirilmiş olan katılım nedeni pratik beceriler geliştirme (\%53.3) olmuştur. Bunu, genel kültür düzeylerini artırmak üzere dil eğitimi alanlar (\%50.8) izlemiştir. Mesleklerinde ilerleme konusunda kendilerine yardımc1 olacağ1 için dil öğrenme istediği \%47'lik bir oranda belirtilmiştir. Akademik kariyer yapma $\% 19.9$ ve iş bulabilmek $\% 13.8$ oranında dile getirilen katılım nedenlerinden olmuştur.

Katılım nedenleri kurumlar dikkate alınarak incelendiğinde, Kadıköy Halk Eğitim Merkezi'nden araştırmaya katılan yetişkinlerin İngilizce öğrenme nedenlerinin başında pratik beceriler geliştirmek (\%57) olduğu görülmektedir. Diller Okulu ve Özel Özkent Lisan Kursu'nda katılım nedenlerinin başında ise meslekte ilerleme olduğu belirlenmiştir. Her üç kurumda da, ikinci sırada yer alan katılım nedenin genel kültür düzeylerini artırmak olduğu görülmektedir. Pratik beceriler geliştirmenin Diller 
Okulu'ndan araştırmaya katılan yetişkinler için genel kültür seviyelerini artırmak ile aynı oranda dile getirildiği belirlenmiştir. Sosyal bağlarını artırmak ya da güçlendirmek ise Kadıköy Halk Eğitim Merkezi'nde ve Özel Özkent Lisan Kursu'nda üçüncü sırada yer almıştır. Sabancı Üniversitesi'nden araştırmaya katılan yetişkinlerin üçüncü sıradaki katılım nedeninin akademik kariyer yapmak olduğu belirlenmiştir. Sosyal bağlarını güçlendirmek bu kurumdan araştırmaya katılan yetişkinler için dördüncü sırada yer almıştır. Diğer yandan, Kadıköy Halk Eğitim Merkezi'nden araştırmaya katılan yetişkinlerin dördüncü sıradaki katılım nedeninin mesleklerinde ilerlemek olduğu görülmektedir. Kadıköy Halk Eğitim Merkezi ve Özel Özkent Lisan Kursu'nda İngilizce öğrenen yetişkinlerin beşinci sırada yer alan katılım nedenlerinin bir iş bulmalarına yardımcı olabileceği düşüncesinin olduğu belirlenmiştir. Bu katılım nedeni, Diller Okulu'nda dil öğrenen yetişkinler tarafından dile getirilmemiştir. Kadıköy Halk Eğitim Merkezi’nden araştırmaya katılan yetişkinlerin altıncı sırada gösterdikleri diğer bir neden ise akademik kariyer yapabilmek olmuştur.

\section{İletişimsel Öğretim Yöntemi’ne Dayalı Andragojik Uygulamalara İlişkin Katılımcı Görüşleri}

İngilizceyi yabancı bir dil olarak öğrenmekte olan yetişkinlerin İ. Ö. Y.'ne dayalı andragojik uygulamalara yönelik görüşlerine ilişkin olarak elde edilen veriler Tablo 3'te görülebilir.

Tablo 3. Illetişimsel ögretim yöntemine dayalı andragojik uygulamalara ilişkin katılımcı görüşleri

\begin{tabular}{|c|c|c|c|c|c|}
\hline \multirow{2}{*}{ İ. Ö. Y.'ne Dayalı Andragojik Uygulama Durumu } & \multicolumn{2}{|c|}{ Evet } & \multicolumn{2}{|c|}{ Hayır } & \multirow[t]{2}{*}{ Toplam } \\
\hline & $\mathrm{f}$ & $\%$ & $\mathrm{f}$ & $\%$ & \\
\hline $\begin{array}{l}\text { Madde 1. Derslerimizde öğretmen ve öğrencilerle } \\
\text { iletişim kurarken İngilizce kullanıyoruz. }\end{array}$ & 189 & 59 & 132 & 41 & 321 \\
\hline $\begin{array}{l}\text { Madde 2. Derslerimizde, ders kitaplarının yanı } \\
\text { sıra gerçek yaşamdan alınan materyaller de } \\
\text { kullanıyoruz. }\end{array}$ & 227 & 71 & 94 & 29 & 321 \\
\hline $\begin{array}{l}\text { Madde 3. İngilizce öğrenme süreci üzerinde } \\
\text { kontrol sahibi olduğumu hissediyorum. }\end{array}$ & 233 & 73 & 88 & 27 & 321 \\
\hline $\begin{array}{l}\text { Madde 4. Derslerimizde kendi yaşam } \\
\text { deneyimlerimden ve diğer öğrenci arkadaşlarımın } \\
\text { yaşam deneyimlerinden bahsediliyor. }\end{array}$ & 260 & 81 & 61 & 19 & 321 \\
\hline Madde 5. Ders hedeflerinin belirlenmesi & 163 & 51 & 158 & 49 & 321 \\
\hline
\end{tabular}


konusunda fikrim alınıyor.

Madde 6. Derslerimizde ne tür faaliyetlerin yapılabileceği konusunda fikir verebiliyorum.

$\begin{array}{lllll}194 & 60 & 127 & 40 & 321\end{array}$

Madde 7. Derslerimizde yapılan faaliyetler ile sınıf dışında gerçekleşen durumlar arasında bağ kurabiliyorum.

Madde 8. Derslerimizde diğer öğrencilerle eşleşerek ikili faaliyetler yapıyoruz.

Madde 9. Derslerimizde grup faaliyetleri yapıyoruz.

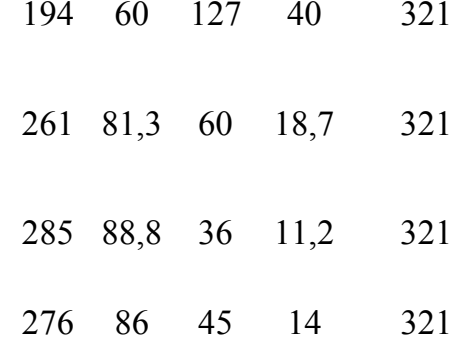

Tablo 3'te İ. Ö. Y.'ne dayalı andragojik ilkelerin katıldıkları programlara tamamen yansıdığına ilişkin olumlu yanıt verilmediği görülmektedir. İlk olarak, gerek öğrenenler arasında gerekse öğrenenler ile öğretmen arasında gerçekleşen her türlü etkileşimde öğrenilmekte olan hedef dilin kullanılması gerektiğinin altına çizen birinci ilkeye olumsuz cevap veren yetişkinlerin oranın \%41 olduğu belirlenmiştir. Ayrıca, katılımcıların \%29'unun derslerinde gerçek yaşamdan alınma materyallerin kullanılmadığını düşündükleri bulunmuştur. Benzer şekilde, yetişkin öğrenenlerin \%27'sinin öğrenmekte oldukları dilin yan1 sıra öğrenme süreçlerine de odaklanma koşuluyla etkin öğrenenler olmalarına izin verecek bir yaklaşımın benimsenmediğini hissettikleri görülmektedir. Ayrıca, katılımcıların yaklaşık 1/5'inin (\%19) tecrübelerinden faydalanılması gerekliliğinin programlarda dikkate alınmadığını düşündükleri belirlenmiştir. Katılımciların hemen hemen yarısının (\%49) ders hedeflerinin belirlenmesinde düşüncelerinin alınmadığını hissetmeleri de önemli bulgular arasındadır. Ders hedeflerine ulaşmak üzere ne tür faaliyetlerin yapılabileceğine ilişkin öğrenenlerden fikir alınması gerektiğinin altını çizen ilkeye, $\% 40$ oranında olumsuz yanıt verildiği dikkati çekmektedir.

Ayrıca katılımcıların gerçek yaşamla bağlantı kurmalarına izin veren uygulamalarda bulunulmadığını düşünenlerin oranın yaklaşık 1/5 (\%18.7) olması önemli bulgular arasındadır. Derslerinde ikili faaliyetlerin yer almadığını düşünenlerin oranın da \%11.2 olduğu belirlenmiştir. Benzer şekilde, grup faaliyetlerinin yapılıp yapılmadığını belirlemek üzere sorulan soruya katılımcıların \%14'ünün olumsuz cevap verdiği görülmektedir.

Özetlemek gerekirse, katılımcıların İ. Ö. Y.'ne dayalı andragojik uygulamalara ilişkin olarak verdikleri yanıtların genel olarak olumlu görülmekle birlikte olumsuz yanıt veren yetişkinlerin sayısının da dikkati çekecek düzeyde olduğu görülmektedir. 


\section{Kurumlara Göre İletișimsel Öğretim Yöntemi’ne Dayalı Andragojik Uygulamalara İlişkin Katılımcı Görüşleri}

Katılımcıların İ. Ö. Y.'ne dayalı andragojik uygulamalara yönelik görüşlerinin, katıldıkları kurumlara göre incelenmesi sonucu elde edilen bulgular Tablo 4'te görülebilir.

Tablo 4'e göre bir takım katılımcı görüşleri arasında kurumlar arası benzerlik bulunmaktadır. Farklı kurumdan araştırmaya katılan bireylerin gerek dil gerekse öğrenme yönetim süreçlerine odaklaşmasına izin verilmesi gerektiğini belirten ilkenin, içerisinde bulundukları öğretim ortamına yansıyıp yansımadığına ilişkin görüşleri arasında istatistiksel olarak anlamlı bir fark bulunmamıştır $\left[\chi^{2}(2)=4.06, p>0.05\right]$. Bu, her üç kurumda İngilizce öğrenen yetişkinlerin gerek özelde öğrendikleri dile gerekse genel olarak öğrenme yönetim süreçlerinde etkin olabildiklerine yönelik algıları arasında benzerlik olduğunu göstermektedir.

Tablo 4. Kurumlara göre iletişimsel ögretim yöntemine dayalı andragojik uygulamalara ilişkin katılımcı görüşleri

\begin{tabular}{|c|c|c|c|c|c|c|c|c|c|}
\hline \multirow{3}{*}{$\begin{array}{l}\text { İ. Ö. Y.'ne } \\
\text { Dayalı } \\
\text { Andragojik } \\
\text { Uygulama } \\
\text { Durumu }\end{array}$} & \multicolumn{2}{|c|}{ K.H.E.M. } & \multicolumn{2}{|c|}{ S.Ü. D.O. } & \multicolumn{2}{|c|}{ Ö.Ö.L.K. } & \multirow[b]{2}{*}{$\mathrm{df}$} & \multirow[b]{2}{*}{$\chi^{2}$} & \multirow[b]{2}{*}{$\mathrm{p}$} \\
\hline & 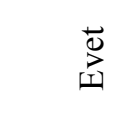 & $\stackrel{\Xi}{\stackrel{\Xi}{I}}$ & $\sum_{[1}^{\vec{D}}$ & $\stackrel{\vec{\Xi}}{\Xi}$ & 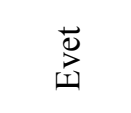 & $\stackrel{\Xi}{\stackrel{\Xi}{\Xi}}$ & & & \\
\hline & $f ; \%$ & $\mathrm{f} ; \%$ & $\mathrm{f} ; \%$ & $\mathrm{f} ; \%$ & $f ; \%$ & $f ; \%$ & & & \\
\hline Madde 1 & $84 ; 42.2$ & $115 ; 57.8$ & $59 ; 86.8$ & $9 ; 13.2$ & $46 ; 85.2$ & $8 ; 14.8$ & 2 & 60.11 & 0.001 \\
\hline Madde 2 & $132 ; 66.3$ & $67 ; 33.7$ & $62 ; 91.2$ & $6 ; 8.8$ & $33 ; 61.1$ & $21 ; 38.9$ & 2 & 18 & 0.001 \\
\hline Madde 3 & $137 ; 68.8$ & $62 ; 31.2$ & $52 ; 76.5$ & $16 ; 23.5$ & $44 ; 81.5$ & $10 ; 18.5$ & 2 & 4.06 & 0.131 \\
\hline Madde 4 & $158 ; 79.4$ & $41 ; 20.6$ & $60 ; 88 ., 2$ & $8 ; 11.8$ & $42 ; 77.8$ & $12 ; 22.2$ & 2 & 0.222 & 3.009 \\
\hline Madde 5 & $108 ; 54.3$ & $91 ; 45.7$ & $31 ; 45.6$ & $37 ; 54.4$ & $24 ; 44.4$ & $30 ; 55.6$ & 2 & 2.57 & 0.277 \\
\hline Madde 6 & $125 ; 62.8$ & $74 ; 37.2$ & $42 ; 61.8$ & $26 ; 38.2$ & $27 ; 50$ & $27 ; 50$ & 2 & 2.98 & 0.225 \\
\hline Madde 7 & $160 ; 80,4$ & $39 ; 19.6$ & $59 ; 86.8$ & $9 ; 13.2$ & $42 ; 77.8$ & $12 ; 22.2$ & 2 & 1.88 & 0.390 \\
\hline Madde 8 & $168 ; 84.4$ & $31 ; 15.6$ & $67 ; 98.5$ & $1 ; 1.5$ & $50 ; 92.6$ & $4 ; 7.4$ & 2 & 11.08 & 0.004 \\
\hline Madde 9 & $161 ; 80.9$ & $38 ; 19.1$ & $67 ; 98.5$ & $1 ; 1.5$ & $48 ; 88.9$ & $6 ; 11.1$ & 2 & 13.52 & 0.001 \\
\hline
\end{tabular}

Benzer şekilde, öğrenenlerin yaşam deneyimlerinden faydalanılması gerektiğini belirten dördüncü ilkeye verilen cevaplar arasında bir farklılık olup olmadığını belirlemek üzere yapılan Ki-kare testi sonucunda istatistiksel olarak anlamlı bir fark bulunmadığ görülmektedir $\left[\chi^{2}(2)=3.009\right.$, $\mathrm{p}>0.05]$.

Diğer bir benzerlik ise, ders hedeflerin belirlenmesinde katılımciların fikrinin alınması gerektiğini belirten İ. Ö. Y.'ne dayalı andragojik ilkeye 
ilişkin katılımcı görüşleri arasında da istatistiksel olarak anlamlı bir fark bulunmamasıdır $\left[\chi^{2}(2)=2.57, p>0.05\right]$. Her üç kurumda da olumsuz yanıt veren katılımcıların oranının yüksek olduğu görülmektedir.

Tablo 4, bu benzerliklere rağmen gerçekleştirilen Ki-kare testleri sonucu istatiksel olarak anlamlı düzeyde farklılıkların gözlemlendiği görüşlerin bulunduğunu göstermektedir. Bunlardan ilki, öğrenenlerin öğrenmekte oldukları dili iletişim aracı olarak kullanmaları gerektiğini belirten ilkenin uygulamaya yansitılıp yansıtılmadığına ilişkin görüşlere verilen yanıtların dağılımları arasındaki farktır $\left[\chi^{2}(2)=60.11, p<0.05\right] . \mathrm{Bu}$ farklılığın, Kadıköy Halk Eğitim Merkezi'nden araştırmaya katılan yetişkin öğrenenlerin önemli bir oranın (\%57.8) vermiş olduğu olumsuz yanıttan kaynaklandığı görülmektedir. Bununla birlikte diğer iki kurumdan araştırmaya katılan yetişkinlerin vermiş olduğu olumsuz yanıtların oranı da dikkat çekmektedir.

Ders kitaplarının yanı sıra gerçek yaşamdan alınan materyallerin kullanılıp kullanılmadığ1 görüşünü belirlemek üzere sorulan soruya verilen yanıtlar arasında da kurumlara göre istatiksel olarak anlamlı düzeyde bir farklılık belirmiştir $\left[\chi^{2}(2)=18, p<0.05\right]$. Diller Okulu'ndan araştırmaya katılan yetişkin öğrenenlerin derslerinde gerçek yaşamdan alınma materyallerin kullanıldığına ilişkin olumlu görüşlerinin oranın daha yüksek olduğu görülmektedir.

Tablo 4'ten, derslerde öğrenenlerin diğer öğrenenlerle ikili faaliyetlerde bulunması gerektiğini belirten sekizinci ilkeye ilişkin katılımc1 görüşlerinin kurumlara göre incelendiğinde istatistiksel olarak anlamlı düzeyde farklılaştığ 1 anlaşılmaktadır $\left[\chi^{2}(2)=11.08, \mathrm{p}<0.05\right]$. Bu maddeye Diller Okulu katılımcilarının yalnızca \%1.5'i olumsuz yanıt verirken, Özkent Lisan Kursu'ndan araştırmaya katılan yetişkinlerin \%7.4'ü olumsuz yanıt vermiştir. Kadıköy Halk Eğitim Merkezi katılımcıları daha yüksek oranla (\%15.6) hayır cevabı vermiştir.

Diğer öğrenenlerle çalışarak grup faaliyetleri yapılması gerektiğini belirten ilkeye ilişkin katılımcı görüşleri arasında kurum değişkenine göre de istatistiksel olarak anlamlı bir fark olduğu görülmektedir $\left[\chi^{2}(2)=13.52\right.$, $\mathrm{p}<0.05]$. Kadıköy Halk Eğitim Merkezi katılımcılarının olumsuz yanıt oranın (\%19.1) en yüksek düzeyde olduğu belirlenmiştir. Özel Özkent Lisan Kursu katılımcilarının olumsuz yanıtlarının oranının ise \%11.1 düzeyinde olduğu belirlenmiştir. Diller Okulu katılımcılarının bu maddeye ilişkin verdikleri olumsuz yanıt oranı (\%1.5) diğer iki kurumun vermiş olduğu olumsuz yanıt oranlarından daha düşük olmuştur. 
Cinsiyete Göre İletişimsel Öğretim Yöntemi’ne Dayalı Andragojik Uygulamalara İlişskin Katılımcı Görüşleri

Katılımcıların İ. Ö. Y.'ne dayalı andragojik uygulamalara yönelik görüşlerinin, cinsiyet değişkeni dikkate alınarak incelenmesi sonucu elde edilen bulgular Tablo 5'te görülebilir.

Tablo 5, katılımcıların İ. Ö. Y.'ne dayalı 9 andragojik ilkenin katıldıkları programlara yansıyıp yansımadığına ilişkin algıları arasında cinsiyete dayalı istatiksel olarak anlamlı düzeyde bir fark bulunmadığını göstermektedir. $\mathrm{Bu}$, her iki cinsiyetten katılımcının alg1 düzeylerinin benzerlik gösterdiğine işaret etmektedir.

Tablo 5. Cinsiyete göre iletişimsel öğretim yöntemine dayalı andragojik uygulamalara iliş̧kin katıllmcı görüşleri

\begin{tabular}{|c|c|c|c|c|c|c|c|c|c|c|c|}
\hline \multirow{3}{*}{$\begin{array}{l}\text { İ. Ö. Y.'ne } \\
\text { Dayalı Andragojik } \\
\text { Uygulama Durumu }\end{array}$} & \multicolumn{4}{|c|}{$\begin{array}{c}\text { Kadin } \\
\mathrm{N}=223\end{array}$} & \multicolumn{4}{|c|}{$\begin{array}{l}\text { Erkek } \\
\mathrm{N}=98\end{array}$} & \multirow{3}{*}{$\mathrm{df}$} & \multirow{3}{*}{$\chi^{2}$} & \multirow{3}{*}{$\mathrm{p}$} \\
\hline & \multicolumn{2}{|c|}{ Evet } & \multicolumn{2}{|c|}{ Hayır } & \multicolumn{2}{|c|}{ Evet } & \multicolumn{2}{|c|}{ Hayır } & & & \\
\hline & f & $\%$ & $\mathrm{f}$ & $\%$ & f & $\%$ & $\mathrm{f}$ & $\%$ & & & \\
\hline Madde 1 & 124 & 56 & 99 & 44 & 65 & 66 & 33 & 34 & 1 & 3.23 & 0.072 \\
\hline Madde 2 & 153 & 69 & 70 & 31 & 74 & 76 & 24 & 24 & 1 & 1.56 & 0.210 \\
\hline Madde 3 & 158 & 71 & 65 & 29 & 75 & 77 & 23 & 23 & 1 & 1.103 & 0.293 \\
\hline Madde 4 & 184 & 83 & 39 & 17 & 76 & 78 & 22 & 22 & 1 & 1.088 & 0.296 \\
\hline Madde 5 & 113 & 51 & 110 & 49 & 50 & 51 & 48 & 49 & 1 & 0.003 & 0.954 \\
\hline Madde 6 & 140 & 63 & 83 & 37 & 54 & 55 & 44 & 45 & 1 & 1.678 & 0.195 \\
\hline Madde 7 & 184 & 83 & 39 & 17 & 77 & 79 & 21 & 21 & 1 & 0.695 & 0.404 \\
\hline Madde 8 & 197 & 88 & 26 & 12 & 88 & 90 & 10 & 10 & 1 & 0.144 & 0.703 \\
\hline Madde 9 & 192 & 86 & 31 & 14 & 84 & 86 & 14 & 14 & 1 & 0.0083 & 0.927 \\
\hline
\end{tabular}

\section{Yaşa Göre İletişimsel Öğretim Yöntemi’ne Dayalı Andragojik Uygulamalara İliş̧kin Katılımcı Görüşleri}

Yaş değişkeni göz önünde bulundurularak, katılımcıların İ. Ö. Y.'ne dayalı andragojik uygulamalara yönelik görüşlerinin farklılaşıp farklılaşmadığına ilişkin elde edilen sonuçlar Tablo 6'da görülebilir. 
Tablo 6. Yaşa göre iletişimsel ögretim yöntemine dayalı andragojik uygulamalara ilişskin katılımcı görüşleri*

\begin{tabular}{|c|c|c|c|c|c|c|c|c|c|c|c|}
\hline \multirow{3}{*}{$\begin{array}{l}\text { İ. Ö. Y.'ne } \\
\text { Dayalı Andragojik } \\
\text { Uygulama Durumu }\end{array}$} & \multicolumn{4}{|c|}{$\begin{array}{c}17-40 \text { yaş } \\
\mathrm{N}=229\end{array}$} & \multicolumn{4}{|c|}{$\begin{array}{c}41 \text { ve üzeri } \\
\mathrm{N}=92\end{array}$} & \multirow{3}{*}{ df } & \multirow{3}{*}{$\chi^{2}$} & \multirow{3}{*}{$\mathrm{p}$} \\
\hline & \multicolumn{2}{|c|}{ Evet } & \multicolumn{2}{|c|}{ Hayır } & \multicolumn{2}{|c|}{ Evet } & \multicolumn{2}{|c|}{ Hayır } & & & \\
\hline & $\mathrm{f}$ & $\%$ & $\mathrm{f}$ & $\%$ & $\mathrm{f}$ & $\%$ & $\mathrm{f}$ & $\%$ & & & \\
\hline Madde 1 & 109 & 48 & 120 & 52 & 80 & 87 & 12 & 13 & 1 & 41.99 & 0.001 \\
\hline Madde 2 & 168 & 73 & 61 & 27 & 67 & 73 & 25 & 27 & 1 & 0.01 & 0.922 \\
\hline Madde 3 & 154 & 67 & 75 & 33 & 79 & 86 & 13 & 14 & 1 & 11.44 & 0.001 \\
\hline Madde 4 & 177 & 77 & 52 & 23 & 83 & 90 & 9 & 10 & 1 & 7.12 & 0.008 \\
\hline Madde 5 & 127 & 55 & 102 & 45 & 36 & 39 & 56 & 61 & 1 & 15.21 & 0.001 \\
\hline Madde 6 & 140 & 61 & 89 & 39 & 54 & 59 & 38 & 41 & 1 & 0.16 & 0.686 \\
\hline Madde 7 & 179 & 78 & 50 & 22 & 82 & 89 & 10 & 11 & 1 & 5.19 & 0.023 \\
\hline Madde 8 & 201 & 88 & 28 & 12 & 84 & 91 & 8 & 09 & 1 & 0.82 & 0.365 \\
\hline Madde 9 & 196 & 86 & 33 & 14 & 80 & 87 & 12 & 13 & 1 & 0.10 & 0.750 \\
\hline
\end{tabular}

*İstatistiksel analizleri mümkün kılmak için orta ve ileri yetişkinlik dönemleri aynı grupta toplanmıştır.

Tablo 6'ya göre farklı yaş grubundan yetişkin öğrenenlerin katıldıkları programlarda İ. Ö. Y.'ne dayalı andragojik uygulama ilkelerinin uygulamaya ne denli yansıdığına ilişkin algılarında benzerlik ve farklılıklar bulunmaktadır. Benzerlikler derslerde ders kitabı yanı sıra gerçek yaşamdan alınan materyallerin de kullanılmas $\left[\chi^{2}(1)=0.01, p>0.05\right]$, yapılmasi planlanan faaliyetler hakkında öğrenenlerin fikirlerini beyan edebilmesi $\left[\chi^{2}(1)\right.$ $=0.16, \mathrm{p}>0.05]$, ikili ve grup faaliyetlerine yer verilmesine ilişkin maddelerde görülmüştür $\left[\chi^{2}(1)=0.82, \mathrm{p}>0.05, \chi^{2}(1)=0.10, \mathrm{p}>0.05\right] . \mathrm{Bu}$ maddeler açısından farklı yaş gruplarından katılımcıların görüşleri arasında istatistiksel olarak anlamlı bir fark bulunmamıştır.

Diğer yandan hedef dilin temel iletişim aracı olarak kullanılması $\left[\chi^{2}(1)\right.$ $=41.99, \mathrm{p}<0.05]$, öğrenenlerin öğrenme sürecinde kontrol sahibi olmaları $\left[\chi^{2}(1)=11.44, p<0.05\right]$, yaşam tecrübelerinden faydalanılmas $\left[\chi^{2}(1)=7.12\right.$, $\mathrm{p}<0.05]$, ders hedeflerinin belirlenmesinde öğrenenlerin katkısının alınması $\left[\chi^{2}(1)=15.21, p<0.05\right]$ ve derslerdeki faaliyetler ile gerçek yaşam arasında bağ kurulabilmesi gerektiğini $\left[\chi^{2}(1)=5.19, p<0.05\right]$ belirten maddelere ilişkin farklı yaş gruplarındaki katılımcıların algıları arasında istatistiksel olarak anlamlı farklar olduğu belirlenmiştir. Öyle ki, beşinci madde haricindeki diğer dört maddeye ilk yetişkinliğe giriş ve ilk yetişkinlik dönemini oluşturan 17-40 yaşları arasındaki katılımcıların verdiği olumsuz yanıt oranın daha yüksek olduğu belirlenmiştir. Genel olarak bakıldığında, daha 
ileri yaştaki yetişkin öğrenenlerin İ. Ö. Y.'ne dayalı andragojik ilkelerin devam ettikleri eğitim programına yansıma düzeyine ilişkin olarak daha olumlu bir algıya sahip oldukları belirlenmiştir.

\section{Eğitim Düzeyine Göre İletişimsel Öğretim Yöntemi'ne Dayalı Andragojik Uygulamalara İlişkin Katılımcı Görüşleri}

Katılımcıların İ. Ö. Y.'ne dayalı andragojik uygulamalara yönelik görüşlerinin, eğitim düzeyi dikkate alınarak incelenmesi sonucu elde edilen bulgular Tablo 7'de görülebilir.

Tablo 7. Eğitim düzeyine göre iletişimsel öğretim yöntemine dayalı andragojik uygulamalara ilişskin katılımcı görüşleri *

\begin{tabular}{|c|c|c|c|c|c|c|c|c|c|c|c|}
\hline \multirow{3}{*}{$\begin{array}{l}\text { İ. Ö. Y.'ne } \\
\text { Dayalı } \\
\text { Andragojik } \\
\text { Uygulama } \\
\text { Durumu }\end{array}$} & \multicolumn{4}{|c|}{$\begin{array}{c}\text { Liseye Kadar } \\
\mathrm{N}=88\end{array}$} & \multicolumn{4}{|c|}{$\begin{array}{c}\text { Yükseköğretim } \\
\mathrm{N}=233 \\
\end{array}$} & \multirow{3}{*}{$\mathrm{df}$} & \multirow{3}{*}{$\chi^{2}$} & \multirow{3}{*}{$\mathrm{p}$} \\
\hline & \multicolumn{2}{|c|}{ Evet } & \multicolumn{2}{|c|}{ Hayır } & \multicolumn{2}{|c|}{ Evet } & \multicolumn{2}{|c|}{ Hayır } & & & \\
\hline & $\mathrm{f}$ & $\%$ & $\mathrm{f}$ & $\%$ & f & $\%$ & $\mathrm{f}$ & $\%$ & & & \\
\hline Madde 1 & 73 & 83 & 15 & 17 & 116 & 50 & 117 & 50 & 1 & 29.03 & 0.001 \\
\hline Madde 2 & 82 & 93 & 6 & 07 & 145 & 62 & 88 & 38 & 1 & 29.58 & 0.001 \\
\hline Madde 3 & 72 & 82 & 16 & 18 & 161 & 69 & 72 & 31 & 1 & 5.19 & 0.023 \\
\hline Madde 4 & 85 & 97 & 3 & 3 & 175 & 75 & 58 & 25 & 1 & 19.15 & 0.001 \\
\hline Madde 5 & 72 & 82 & 16 & 18 & 189 & 81 & 44 & 19 & 1 & 0.02 & 0.886 \\
\hline Madde 6 & 42 & 48 & 44 & 50 & 152 & 65 & 81 & 35 & 1 & 7.09 & 0.008 \\
\hline Madde 7 & 61 & 69 & 27 & 31 & 200 & 86 & 33 & 14 & 1 & 11.47 & 0.001 \\
\hline Madde 8 & 86 & 98 & 2 & 2 & 199 & 85 & 34 & 15 & 1 & 9.94 & 0.002 \\
\hline Madde 9 & 75 & 85 & 13 & 15 & 201 & 86 & 32 & 14 & 1 & 0.06 & 0.811 \\
\hline
\end{tabular}

* İstatistiksel analizleri mümkün kılmak için ilköğretim-lise arası eğitim düzeyleri aynı grupta toplanmıştır.

Tablo 7'ye genel olarak bakıldığında farklı eğitim düzeylerinden katılımcıların maddelere verdiği yanıtlardan iki tanesine ilişkin benzerlik bulunduğu görülmektedir. Bu benzerlik ders hedeflerin belirlenmesinde katılımcıların görüşlerinin alınması gerektiğini belirten beşinci madde ve derslerde grup faaliyetlerinin kullanılması gerektiğini belirten dokuzuncu maddeye ilişkin bildirilen görüşler arasında istatiksel olarak anlamlı bir fark bulunmayışından kaynaklanmıştır $\left[\chi^{2}(1)=0.02, \mathrm{p}>0.05, \chi^{2}(1)=0.06, \mathrm{p}>0.05\right]$. Her iki gruptan da bu maddelere olumlu görüş bildiren katılımcıların oranı daha yüksek olmuştur (\%82 -\%81 ve \%85-\%86).

$\mathrm{Bu}$ benzerliğe rağmen, yedi maddeye ilişkin katılımcı görüşleri arasında istatistiksel olarak anlamlı farklar bulunmuştur. Temel iletişim aracı olarak İngilizcenin kullanılması $\left[\chi^{2}(1)=29.03, p<0.05\right]$, derslerde gerçek 
yaşamdan alınan materyal kullanılması $\left[\chi^{2}(1)=29.58, p<0.05\right]$, öğrenme süreci üzerinde yetişkin öğrenenlerin kontrol sahibi olduklarını hissetmesi $\left[\chi^{2}(1)=5.19, p<0.05\right]$, yaşam deneyimlerinden faydalanılmas $\left[\chi^{2}(1)=19.15\right.$, $\mathrm{p}<0.05]$, yapılması planlanan faaliyetler konusunda öğrenenlerin görüşlerinin alınması $\left[\chi^{2}(1)=7.09, p<0.05\right]$, öğrenenlerin sınıf içi çalışmalar ve gerçek yaşam arasında bağ kurabilmeleri $\left[\chi^{2}(1)=11.47, \mathrm{p}<0.05\right]$ ve ikili faaliyetlerde bulunulması gerektiğini vurgulayan $\left[\chi^{2}(1)=9.94, \mathrm{p}<0.05\right]$ maddelere verilen katılımcı görüşleri anlamlı düzeyde farklılaşmıştır. Altıncı ve yedinci maddeler haricinde, yükseköğretim düzeyinde bir diplomaya sahip katılımcıların verdikleri olumsuz görüş oranının, lise ve altı düzeyde diploma sahibi katılımcılarınınkinden daha yüksek olduğu belirlenmiştir. $\mathrm{Bu}$ durum, eğitim seviyesi yükseldikçe katılımcıların İ. Ö. Y.'ne dayalı andragojik uygulama ilkelerinin öğrenme ortamına yansıtıldığına ilişkin olumlu görüş oranının genel olarak azalmakta olduğuna işaret etmektedir.

\section{TARTIŞMA VE SONUÇ}

İngilizceyi yabancı bir dil olarak öğrenen yetişkinlerin demografik özelliklerini, katılım nedenlerini ve öğrenim gördükleri kurumlardaki uygulamalara ilişkin görüşlerini belirlemeyi amaç edinen bu çalışmada aşağıdaki sonuçlar elde edilmiştir.

Çalışmaya katılan yetişkin öğrenenlerin çoğunluğunu kadınların oluşturduğu belirlenmiş ve kadın katılımcıların 159 sayı ile çoğunluğunun Kadıköy Halk Eğitim Merkezi'nden olduğu dikkati çekmiştir. Bu durum Halk Eğitim merkezlerinin sunduğu faaliyetlerden faydalananların genel olarak kadınlar olduğunu belirlemiş olan Okçabol'un (1994) bulguları ile paralellik göstermektedir. Benzer şekilde Ural (2007) Halk Eğitim Merkezleri kurslarına katılanların büyük çoğunluğunun genç kadınlar olduğuna dikkat çekmektedir. Yavaşça (2010) da Halk Eğitim Merkezleri'ndeki İngilizce kurslarına katılan kadın katılımcıların sayısının, erkek katılımcı sayısından bir buçuk kat daha fazla olduğunu bulmuştur.

Katılımcıların çoğunluğunun ilk yetişkinliğe geçiş ve ilk yetişkinlik döneminde olduğu görülmüştür. Benzer şekilde Deveci (2007) de özel eğitim kurumlarında İngilizce eğitimi alan yetişkinlerin çoğunluğunun ilk yetişkinliğe geçiş ve ilk yetişkinlik yılları arasında olduğunu bulmuştur. Karataş (2009) da araştırmasında katılımcıların çoğunluğunun 40 yaş grubunda olduğunu belirlemiştir. Ancak Ural (2007) halk eğitimi faaliyetlerine katılımı inceleyen farklı araştırmaların bulgularını karşılaştırmış ve Halk Eğitim Merkezlerinin yürüttüğü kurslara katılanların çoğunluğunun 15-24 yaş arasındaki genç kadınlardan oluştuğunu belirlemiştir. Benzer şekilde Yavaşça (2010), Çankaya ve Mamak Halk 
Eğitim Merkezlerinde 75 kişi üzerinde yaptığı çalışmasında İngilizce öğrenmekte olan yetişkinlerin çoğunluğunun ilk yetişkinliğe geçiş ve ilk yetişkinlik yıllarını kapsayan yaş aralığında olduğunu bulmuştur. $\mathrm{Bu}$ araştırmadaki bulgu ile paralellik göstermemekle birlikte bunun bir sebebi olarak araştırmada incelenen eğitim faaliyetinin dil öğrenimi gibi belirli bir alanla sınırlı olması gösterilebilir.

Eğitim seviyesi ile ilgili olarak katılımcıların çoğunluğunun bir yükseköğretim kurumundan mezun oldukları belirlenmiştir. Araştırmanın bu bulgusuna benzer şekilde, Yavaşça (2010) Halk Eğitim Merkezlerinde yabanc1 bir dil olarak İngilizce öğrenen yetişkinlerin çoğunluğunun lisans mezunu olduğunu bulmuştur. Bu durum, yabancı bir dil öğrenme eğiliminde olan yetişkinlerin daha çok yükseköğrenim seviyesinde olduklarına işaret etmektedir.

Katılım nedenleri incelendiğinde ise, araştırmaya katılan yetişkinlerin daha çok pratik beceriler geliştirmek istedikleri belirlenmiştir. Genel kültür düzeylerini artırmak ve mesleklerinde ilerlemek üzere yabancı dil öğrenmek isteyenlerin sayısı da dikkati çekmektedir. Benzer şekilde, Cıngıllıŏlu (2005) özel kurslarda İngilizce öğrenmekte olan yetişkinlerin işlerinde terfi etmek ve(ya) daha yüksek ücretli bir iş bulmak gibi nedenlere sahip olduklarını belirlemiştir. Halk Eğitim merkezlerinin sunmuş olduğu eğitim faaliyetlerine katılım nedenlerini inceleyen diğer araştırmalar da bireylerin gelir getirici kursları tercih ettiklerini bulmuştur (Ural, 1993; Ada, 2003; Yavaşça, 2010). Bu araştırmada, katılımcıların sosyal bağlarını artırmak ya da güçlendirmek nedeniyle programa devam etmeleri de önemli bulgular arasındadır. Benzer şekilde, Halk eğitimi kurslarına katılma nedenleri arasında Ural (1993) sosyal ilişki kurma ve Ayhan (1990) yeni insanlarla tanışma türünden sosyal bağlar oluşturma nedenlerini saptamıştırlar.

$\mathrm{Bu}$ araştırmanın önemli bulgularından diğeri de, katılımcıların İ. Ö. Y.'ne dayalı andragojik uygulamalara ilişkin görüşlerine dair verdikleri olumsuz yanıtların oranının önemli düzeyde olmasıdır. Dedef dilin temel iletişim aracı olarak kullanılmadığı belirlenmiştir. Ayrıca yetişkinlerin öğrenmeyi anlamlı bulması için gerçek yaşamla bağlantı kurabilmeleri gerekmektedir. Aksi taktirde, öğrenme ortamından uzaklaşmaları olasıdır. $\mathrm{Bu}$ araştırmaya katılan yetişkin öğrenenlerin yaklaşı \%20'sinin dahil oldukları programda buna dikkat edilmediğini düşünmesi önemlidir. Öğrenenler arasındaki etkileşimi artırmasına ve birbirlerinin öğrenmelerine katkıda bulunmasına yardımcı olacağı beklenen ikili faaliyetlerinin yapılıp yapılmadığına büyük bir çoğunluğun olumlu yanıt vermesine rağmen, \%11.2 oranında bir grubun olumsuz yanıt vermiş olması da önemli bulgular arasındadır. Grup faaliyetlerinin yapılıp yapılmadığını belirlemek üzere sorulan soruya katılımciların \%14'ünün olumsuz cevap verdiği 
görülmektedir. Ayrıca, katılımcıların yaklaşık 1/5'inin (\%19) İ. Ö. Y.'ne dayalı andragojik uygulamaların ana ilkelerinden biri olan yetişkin öğrenenlerin yaşam tecrübelerinden faydalanılması gerekliliğinin programlarda dikkate alınmadığını düşündükleri belirlenmiştir.

Katılımc1 görüşlerinin kurumlara göre incelenmesi sonucu elde edilen verilerde Kadıköy Halk Eğitim Merkezi’ndeki uygulamalarda hedef dilin iletişim aracı olarak kullanılmadığına ilişkin bulgu dikkat çekicidir. Benzer şekilde, Kadıköy Halk Eğitim Merkezi'nde katılımcıların birbirleri ile iletişim haline geçerek dili öğrenmelerine izin verecek olan grup çalışmalarından faydalanılmadığına ilişkin görüşlerindeki farklılık da dikkat çekicidir. Genel olarak bakıldığında, yetişkin öğrenenlerin temel öğrenme merkezlerinden biri olarak görülmesi beklenen ve daha fazla sayıda yetişkin çeken Kadıköy Halk Eğitim Merkezi'nde İ. Ö. Y.'ne dayalı andragojik uygulamalara diğer iki kuruma göre daha az dikkat edildiği görülmektedir.

Katılımc1 görüşlerinin demografik özelliklere göre incelenmesi sonucu elde edilen veriler ise önemli benzerliklerle birlikte farklılıkların da olduğunu göstermiştir. Cinsiyet değişkeni göz önünde bulundurulduğunda katılımcıların İ. Ö. Y.'ne dayalı andragojik uygulamalara ilişkin algılarının farklılaşmadığ 1 görülmüş̧ür. Ancak yaş değişkeni dikkate alındığında ilk yetişkinliğe giriş ve ilk yetişkinlik yılları içerisindeki yetişkinlerin derslerinde hedef dilin temel iletişim aracı olarak kullanıldığına, öğrenme süreci üzerinde kontrol sahibi olduklarına, yaşam tecrübelerinden yeterince faydalanıldığına ve ders hedeflerinin belirlenmesine katkıda bulunabildiklerine ilişkin olarak daha az olumlu hisler besledikleri görülmüştür. Buna benzer olarak eğitim seviyesi daha yüksek olan katılımcıların hedef dilin kullanıldığına, gerçek yaşamdan alınma materyallerin kullanıldığına, öğrenme süreci üzerinde kontrol sahibi olduklarını hissettiklerine, yaşam deneyimlerinden faydalanıldığına ve ikili faaliyetlerin yapıldığına ilişkin olarak nispeten daha az olumlu hissettikleri belirlenmiştir. Bu bulgular, bir yetişkin eğitimi faaliyeti olarak yabancı dil öğrenen yetişkinlerin özellikle yaş ve eğitim açısından demografik özelliklerinin yeterince göz önünde bulundurulmadığına işaret etmektedir. Bangura (1996) da buna benzer bulguları, yetişkinlere yönelik olarak hazırlanan 31 adet dil öğretim kitabi ve 25 adet müfredatı incelemiş olduğu çalışmasında dile getirilmiş ve yabancı dil öğrenen yetişkinlerin andragojik temelli dil eğitimine daha fazla maruz kalması gerekliliğinin altını çizmiştir.

Yukarıda ana hatları ile betimlenmiş olan görüşlerden yola çıkarak bu çalışmaya katılan yetişkin öğrenenlerin tam olarak andragojik temelli bir eğitim almadıkları söylenebilir. Bu durumun yetişkinlerin dil öğrenimindeki başarı düzeyini olumsuz şekilde etkileyeceği savunulabilir. Öyle ki, daha 
önce yapılmış olan araştırmalar (Akin, 2011; Bishop, 2006) andragojik temellerle yürütülen İngilizce dil öğretimi programlarının daha etkili sonuçlar verdiğini ampirik olarak kanıtlamışlardır.

Yetişkin eğitimi faaliyetlerinden faydalanan katılımcıların demografik özellikleri incelendiğinde ortaya çıkan bu genel tablo, eğitim faaliyetlerinin daha etkin planlanması, yürütülmesi ve değerlendirilmesine yardımcı olacak bir takım önerilere işaret etmektedir. Farklı eğitim faaliyetlerinin içeriği ile katılımcı özellikleri dikkate alınarak hazırlanacak olan programlarda farklılıklar olması beklenmekle birlikte, özellikle yabancı dil eğitimi yapılan programlar başta olmak üzere tüm yetişkin eğitimi faaliyetlerinin daha başarılı olması için şu önerilerde bulunabilir:

1. Sunulan dil eğitim programları tek bir kalıba uyacak şekilde planlanmak yerine, katılımciların katılım nedenleri dikkate alınarak sınıflar oluşturulmalı, bu sınıflarda katılım nedenlerine yönelik ders kitabı ve sınıf içi uygulamalara yer verilmelidir.

2. Pratik becerilerin geliştirilmesi, genel kültür seviyesinin artırılması ve sosyal bağların güçlendirilmesi gibi yaygın olarak beliren katılım nedenlerinin sosyal etkileşime dayalı öğrenme faaliyetleri yardımıyla karşılanmasına gayret edilmelidir.

3. Yetişkinler için düzenlenen dil eğitimi programlarında İ. Ö. Y. ilkelerine dayalı andragojik uygulamalara daha fazla yer verilmelidir. Gerçek yaşamla bağlantı kurabildikleri, kendi yaşam tecrübelerinin eğitim materyali olarak kullanılabileceği türden uygulamalara yer verilmelidir.

4. Halk Eğitim Merkezleri'nde yabancı dil öğrenen yetişkinler arasında kadınların çoğunluğu oluşturma eğilimi dikkate alınırsa, yabancı dil eğitim programları kadınların ihtiyaç duydukları konulara yoğunlaşabilir.

5. Gerek eğitim faaliyetlerini planlayanların gerekse uygulayanların İ. Ö. Y.'ne dayalı andragojik uygulamalara ilişkin farkındalıklarının artırılacağı hizmet öncesi ve hizmet içi eğitim faaliyetleri düzenlenmelidir.

6. Yetişkin katılımcıların kendi özelliklerini tanımalarına fırsat verecek uygulamalara yer verilmelidir. $\mathrm{Bu}$ amaçla dil eğitiminde kullanılan materyaller arasında yetişkin öğrenenlerinin özelliklerini anlatan türden okuma ya da dinleme materyallerinden faydalanılabilir. 


\section{KAYNAKLAR}

Ada, S. (2003). Halk Eğitimi Merkezlerindeki Kurslara Katılan Bayan Kursiyerlerin Çevre ve İnsan Sağlığı ile İlgili Uygulamalarının Saptanması, M. Ü. Atatürk Ĕgitim Fakültesi Eğitim Bilimleri Dergisi, 17. 1-12.

Akın, G. (2010). "Andragojik İlkelere Göre Geliştirilmiş Problem Temelli Mesleki İngilizce Eğitimi Programının Etkililiği." Yayımlanmamış doktora tezi, Ankara Üniversitesi Eğitim Bilimleri Enstitüsü, Ankara.

Akın, G. (2011). Polis Akademisi Öğrencileri İçin Andragojik İlkelere Göre Geliştirilmiş Problem Temelli Mesleki İngilizce Eğitimi Programının Etkililiği. Polis Bilimleri Dergisi, 13(1), 115-136.

Aşır, M. (2009). "Yetişkinlerde İngilizce Öğretiminde Uygulanan Yöntemlerin, Andragojik Varsayımlara Uygunluğunun Değerlendirilmesi.” Yayımlanmamış yüksek lisans tezi, Ankara Üniversitesi Eğitim Bilimleri Enstitüsü, Ankara.

Ayhan, S. (1990). Halk Eğitiminde Katılma İle İlgili Araştırmalar. Eğitim Bilimleri Fakültesi Dergisi, 23(1), 307-332.

Bangura, A. K. (1996). "Pedagogy and foreign language teaching in the United States: Andragogy to rescue." Paper presented at Odyssey of the Mind Association International Conference on Nurterin Creativity and Problem Solving in Education, Washington, DC.

Bishop, G. (2006). True independent learning -an andragogical appraoch: giving control to the learner over choice of material and design of the study session. Language Learning Journal, 33, 40-6.

Brown, C. B. (2002). A model of SLA and its Andragogical implications in teaching EFL to young adult Japanese learners, The Language Teacher, Retrieved on 27-September-2011, at URL: http://www.jaltpublications.org/old_tlt/articles/2002/03/brown

Cingıllıoğlu, S. (2005). "Reasons Behind Dropouts in Adult Education: A Survey with Students of Private English Language Courses in İstanbul." Yayımlanmamış yüksek lisans tezi, Boğaziçi Üniversitesi Sosyal Bilimler Enstitüsü, İstanbul.

Cox, T. D. (2013). Adult learning orientations: The case of languages teachers in Peru. International Forum of Teaching \& Studies, 9(1), 3-10.

Davenport, J. \& Davenport, J. H. (1985). Knowles or Lindeman: Would the real father of American andragogy please stand up?. Lifelong Learning, 9 (3), 4- 5.

Davenport, J. \& Davenport, J. A. (1986). Anragogical-pedagogical orientation and its relationship to selected variables among university students, A Journal Pertaining to College Students, (20) 2, 130-138.

Deveci, T. (2007). Andragogical and pedagogical orientations of adult learners learning English as a foreign Language. New Horizons in Adult Education and Human Resource Development, 21(3/4), 16-28.

Finnochiaro. M. \& Brumfit, C.J. (1983). The functional-notional Approach: From Theory to Practice. New York: Oxford University Press.

Karasar, N. (1994). Bilimsel Araştırma Yöntemi. Ankara: 3A Araştırma Eğitim Danışmanlık Ltd. Şti. Basımevi. 
Karataş, S.E. (2009). "Yetişkinlerin Eğitime Katılma Güdüsünü Etkileyen Psikolojik ve Toplumsal Faktörler -Karayolları Genel Müdürlüğü İngilizce Eğitimleri Örneği." Yayımlanmamış yüksek lisan tezi, Ankara Üniversitesi Eğitim Bilimleri Enstitüsü, Ankara.

Knowles, M. (1996). Yetişkin Öğrenenler: Göz Ardı Edilen Bir Kesim, (Çev. S. Ayhan). Ankara: Ankara Üniversitesi Basımevi.

Knowles, M. (1980). The modern practice of adult education: From pedagogy to andragogy, New York: Cambridge Books.

Kovacevic, E. (2011). "Presence of andragogical principles in English Language Teaching Practice." Paper presented at 1st International Conference on Foreign Language Teaching and Applied Linguistics, Sarajevo.

Mangubhai, F., Marland.P, Dashwood, A. \& Son, J.B. (2004). Teaching a foreign language: one teacher's practical theory. Teaching and Teacher Education. 20, 291-311.

McCombs, B. L. (1991). Motivation and lifelong learning. Educational Psychologist, 26(2), 117-127.

Nunan, D. (1991). Language teaching methodology. London: Prentice Hall International.

Nunan, D. (1999). Second language teaching and learning. Boston: Heinle \& Heinle Publishers.

Okçabol, R. (1994). Halk Eğitimi (Yetişkin Eğitimi). İstanbul: Der Yayınları.

Richards, J., C. \& Rodgers, T. (1986). Approaches and methods in language teaching: a description and analysis. Cambridge: CUP.

Savignon, S. J. (2002). Communicative language teaching: linguistic theory and classroom practice. In S. J. Savignon (Ed.). Interpreting Communicative Language Teaching. (pp. 1-27). New Haven \& London: Yale University Press.

Segalowitz, N. \& Lightbown, P, M. (1999). Psycholinguistic approaches to SLA. Annual Review of Applied Linguistics. 19, 43-63

Ural, O. (1993). "The Reasons for Participating in Adult Education Programs in Turkey." Yayımlanmamış doktora tezi, Boğaziçi Üniversitesi, İstanbul.

Ural, O. (2007). Türkiye'de Yetişkin Eğitiminin Bugünkü Durumu ve Geleceği, Ísmek Öğrenen Toplum İçin Yetişkin Eğitimi Sempozyumu Bildirileri, İstanbul.

Yavaşça, O. (2010). "Yabancı Dil Öğrenen Yetişkinlerin Grup Dinamiğinin ve Sınıf Atmosferinin Dil Öğrenmeye Etkisine İlişkin Görüşler." Yayımlanmamış yüksek lisan tezi, Ankara Üniversitesi Eğitim Bilimleri Enstitüsü, Ankara. 
